\title{
A 14 YEAR-OLD GIRL WITH TURNER SYNDROME OF COMPLICATED KARYOTYPE; $45, \mathrm{X} / 47, \mathrm{XY},+18,-19,+\operatorname{der}(19), \mathrm{t}(\mathrm{Y} ; 19)(\mathrm{q} 12 ; \mathrm{p} 13.3)$
}

\author{
Shizuhiro Ninhra, Hiroko Fujita, ${ }^{1}$ Norimitu Otzuka, Tomoko Hashimoto, ${ }^{2}$ \\ Mamoru NAGANO, and Takuma KonDoU ${ }^{3}$ \\ ${ }^{1}$ Department of Child Health, Osaka City University, Sugimoto, \\ Sumiyoshi-ku, Osaka 558, Japan \\ ${ }^{2}$ Hyogo College of Medicine, Mukogawa-cho, Nishinomiya, \\ Hyogo 663, Japan \\ ${ }^{3}$ Children's Medical Center of Osaka City, Higashinakamoto, \\ Higashinari-ku, Osaka 537, Japan
}

\begin{abstract}
Summary This paper reports a rare case of complicated karyotype $: 45, \mathrm{X} / 47, \mathrm{XY},+18,-19,+\operatorname{der}(19), \mathrm{t}(\mathrm{Y} ; 19)(\mathrm{q} 12 ; \mathrm{p} 13.3)$. The culture of skin fibroblasts, however, showed only $45, X$ cells. The patient, 14-year-old girl, exhibited Turner syndrome and mixed gonadal dysgenesis. There were no clinical features of 18 trisomy except for a short sterunum and moderate mental retardation. The inconsistency of the phenotype with the observed karyotype is discussed.
\end{abstract}

\section{INTRODUCTION}

Two cases of $45, \mathrm{X} / 47, \mathrm{XY},+18$ mosaicism have been described (Schinzel et al., 1974; Serville et al., 1977). There are apparently no case, however, in which $Y / 19$ translocation was associated with this mosaicism. We here describe the first case of mosaicism 45,X/47,XY, +18, - 19, +, der(19),t(Y;19)(q12;p13.3).

\section{CASE REPORT}

This 14-year-old girl, born on February 10, 1970, was sent to the Osaka Child Health Center for evaluation of short stature and mental retardation on February 22, 1984.

This patient was the product of a full term pregnancy and caesarean section delivery because of breech. Soon after birth, she was placed in an intensive care ward for one week because of anoxia. Birth weight was $2,280 \mathrm{~g}$. The father was 25 and the mother 26 years of age at the time of her birth. Their only other child is a 10-year-old boy. There is no family history of short stature and mental retardation. 
Developmental milestones included walking at 22 months of age and talking in two-word sentences at 3 years of age.

Physical examination revealed the following stigmata of Turner syndrome, short stature (body length $122.4 \mathrm{~cm},-6.3 \mathrm{SD}$, body weight $24.2 \mathrm{~kg},-3.2 \mathrm{SD}$ ), low posterior hair line, broad chest with widely spaced nipples, cubitus valgus and lack of second sexual development. She exhibited no features of 18 trisomy except for a short sternum and growth and mental retardation ( $\mathrm{IQ}=50$ ) (Fig. 1).

Dermatoglyphic patterns are also not consistent with 18 trisomy: she had no arch but 2 whorls and 8 loops on her finger tips, both axial triradii in t-position, and no simian crease on palms.

Laboratory examinations were within normal limits with the exception of endocrinological tests of the pituitary-gonadal system. The latter showed "Turner-like" pattern; LH and FSH were extremely elevated and abnormally high and prolonged response to LH-RH injection. Serum estradiol was $9.9 \mathrm{pg} / \mathrm{ml}$, which was below the normal female range for 14 years of age $(16.3-130.7 \mathrm{pg} / \mathrm{ml})$; serum testosterone was $41.8 \mathrm{ng} / \mathrm{dl}$, slightly higher than the normal female level $(18-38 \mathrm{ng} / \mathrm{dl})$.

Since she had Y chromosome in her cells, laparotomy was performed. It revealed the presence of a hypoplastic uterus, oviduct with tubular structure, round ligaments, and gonads in the normal position. Histological examination of gonads demonstrated a streak appearance in the left side and an ovotestis with dysgenetic

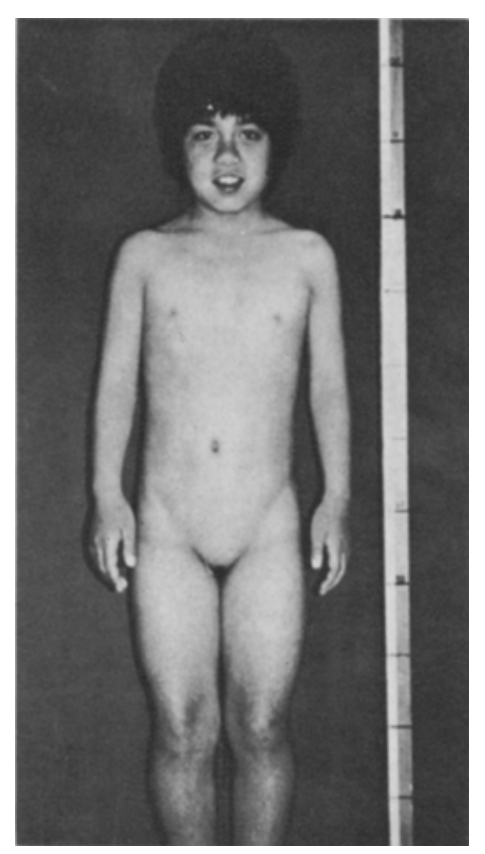

Fig. 1. Front view of the present case at 14 years of age. 


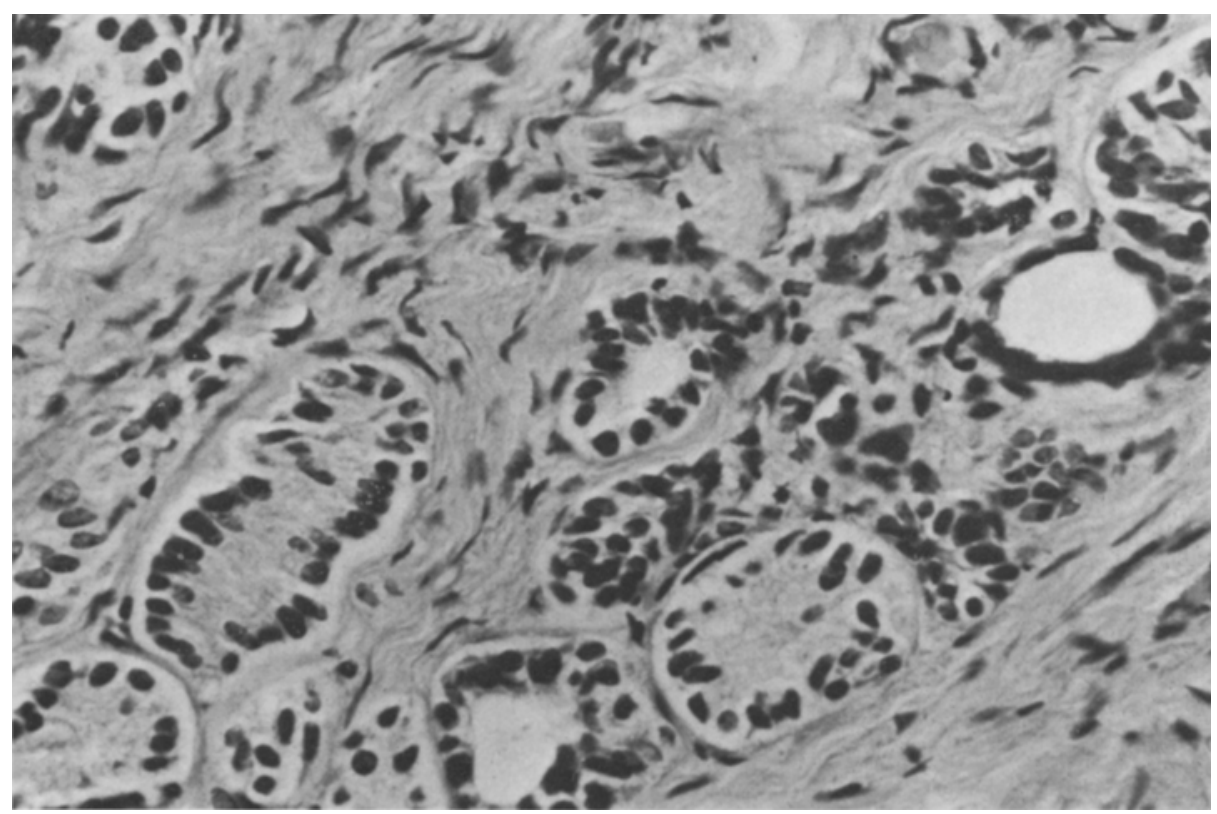

Fig. 2. Histological examination; dysgenetic seminiferous tubules in the right gonad.

seminiferous tubules and ovarian interstitial cells on the right. The diagnosis was mixed gonadal dysgenesis (Fig. 2).

\section{CYTOGENETIC STUDIES}

Chromosomal analysis was carried out on peripheral blood cultures and revealed two cell populations: one was $45, X$ and the other $47, X Y,+18,19 p+$. The latter was found in about a half of mitotic spreads. One distinct dark band attaching to the distal portion of a short arm of a no. 19 chromosome was disclosed by G-banding. Quinacrine banding identified this extra band as a brightly fluorescent part of Yq12 band (Fig. 3). Interphase nuclei of leucocyte showed two fluorescent Y bodies. One of which was smaller than the other (Fig. 4).

The cultures of skin fibroblast showed only $45, \mathrm{X}$ in 100 cells observed (Table 1). No X chromatin body was detected in buccal epithelial cells.

$\mathrm{G}$ and Q-banded karyotypes of her father and brother were normal. A free $Y$ chromosome of the patient was morphologically the same as the father's. Karyotype of the mother was also normal. 


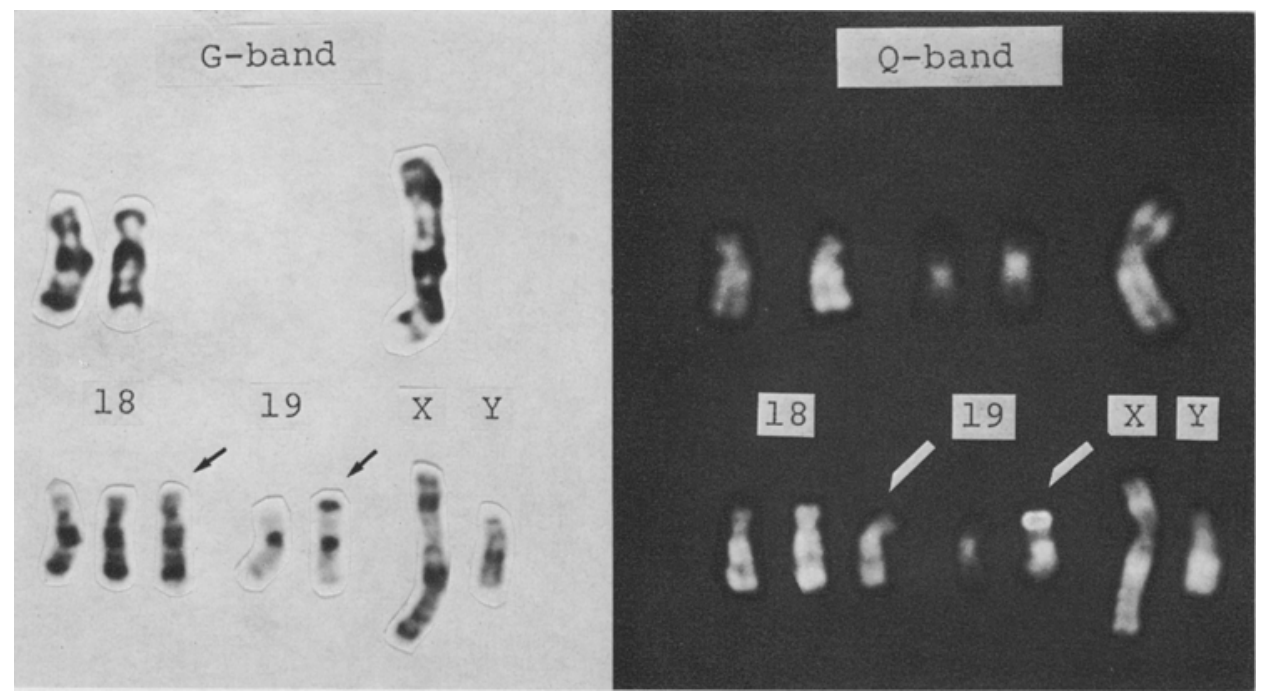

Fig. 3. $G$ and $Q$-banded karyotypes of present case. The upper line shows cells with $45, X$ karyotype and the lower line shows that with $47, X Y,+18,-19,+\operatorname{der}(19)$, $t(Y ; 19)(q 12 ; q 13.3)$. Arrows show trisomy 18 and $Y / 19$ translocation; the extra band of der(19) chromosome appeared to be derived of brightly fluorescent segment of $\mathrm{Yq}$.

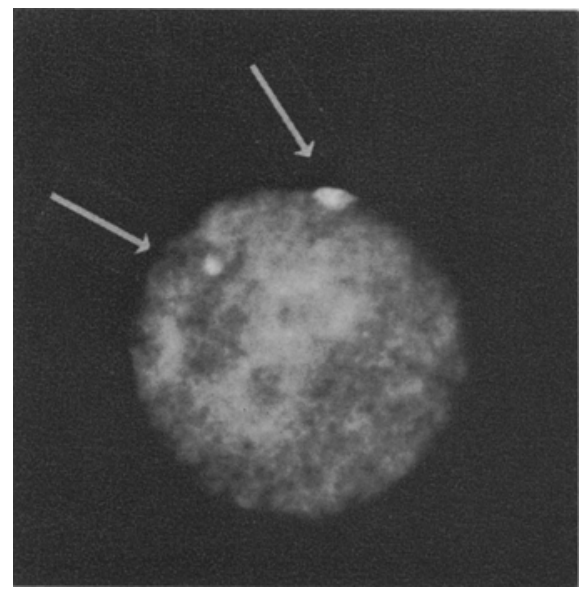

Fig. 4. Two $Y$ bodies in interphase nucleus of leukocyte.

Table 1. Chromosome constitution.




Table 2. Comparison with two previously reported patients with $45, \mathrm{X} / 47, \mathrm{XY},+18$.

\begin{tabular}{|c|c|c|c|c|}
\hline \multicolumn{2}{|l|}{$\begin{array}{l}\text { Author } \\
\text { (year) }\end{array}$} & $\begin{array}{c}\text { Schinze] } \\
\text { (1974) }\end{array}$ & $\begin{array}{l}\text { Serville } \\
\text { (1977) }\end{array}$ & Present case \\
\hline \multicolumn{2}{|c|}{ Legal sex \& Age } & female, $14 y$ & female, $11 \mathrm{~m}$ & female, $14 y$ \\
\hline \multirow[t]{2}{*}{ Karyotype } & $\%$ of $45, \mathrm{X}$ in blood & $60 \%$ & $53 \%$ & $52 \%$ \\
\hline & $\%$ of $45, \mathrm{X}$ in skin & $93 \%$ & $100 \%$ & $100 \%$ \\
\hline \multirow[t]{6}{*}{ Phenotype } & 18-trisomy & - & - & - \\
\hline & Mental retardation & - & + & + \\
\hline & Turner syndrome & + & + & + \\
\hline & External genitalia & female & female & female \\
\hline & Internal genitalia & female $^{2}$ & female $^{a}$ & female $^{a}$ \\
\hline & Gonad & streak & streak & $b$ \\
\hline
\end{tabular}

${ }^{a}$ Hypoplastic uterus with oviducts. b Mixed gonadal dysgenesis.

\section{DISCUSSION}

The case presented here showed a very complicated karyotype containing two abnormal cell lines: one had an X-monosomy and the other had trisomy 18 and $Y / 19$ translocation. To our knowledge there has been no previous report of such combination of chromosomal abnormalities in one person. The phenotype of two previously reported cases with $\mathrm{X} / \mathrm{XY}$ associated with mosaic 18 trisomy is summarized in Table 2.

Each of the three patients showed the phenotype of Turner syndrome without characteristic manifestations of 18 trisomy, except for mental retardation in two of them. All the three patients showed female type of external and internal genitalia and streak gonads, although our patient's gonads contained a few dysgenetic seminiferous tubules and ovarian interstitial cells.

We were unable to know the reason why the trisomic cells had such a little influence on the phenotype in the three patients.

One possible explanation would be that 18 trisomic cells vanished in many organs during early fetal development.

\section{REFERENCES}

Schinzel, A., Schmid, W., and Prader, A. 1974. Turner phenotype: Mosaic 45,X/47,XY, +18 . J. Med. Genet. 11: 101-104.

Serville, F., Fontan, D., Laurent, C., Cazauran, J.M., and Verger, P. 1977. Mosaic 45,X/47,XY, 18. Hum. Genet. 36: 351-353. 